\title{
Remoblization and Injection in Deepwater Depositional Systems: Implications for Reservoir Architecture and Prediction
}

\author{
Lidia Lonergan \\ Nick Lee \\ Howard D. Johnson \\ T.H. Huxley School of Environment Earth Sciences and Engineering \\ Imperial College of Science Technology and Medicine \\ Prince Consort \\ London SW7 2BP UK \\ 1.lonergan@ic.ac.uk \\ Joe A. Cartwright \\ Department of Earth Sciences \\ Cardiff University \\ Cardiff CF1 3YE Wales \\ Richard J.H. Jolly \\ Golder Associates (UK) Limited \\ First Floor, Clyde House \\ Reform Road, Maidenhead \\ Berkshire SL6 8BY UK
}

\begin{abstract}
Several productive Paleogene deepwater sandstone reservoirs in the North Sea show evidence of having undergone post-depositional remobilization and clastic injection, which can result in major disruption of the primary reservoir distribution (e.g., Alba, Forth/Harding, Balder, and Gryphon fields). Case studies of deepwater sandstones from UK Quadrants 9, 15, 16 and 21 are presented to illustrate the wide spectrum of remobilization features, which range from centimeters (e.g., core-scale) to hundreds of meters (e.g., seismic-scale). Most common are clastic injection structures such as dikes and sills. Sills of massive sand, over $20 \mathrm{~m}$ thick, have been identified. Intrusions associated with the propagation of syn- to early post-depositional, dewatering-related polygonal fault systems in adjacent deepwater mudrocks are also common. The scale of the clastic intrusion and remobilization has significant impact on reservoir architecture and production performance, including changes in (a) original depositional geometries; (b) reservoir properties; (c) connectivity, (d) top reservoir surface structure, (e) reservoir volumetrics, and (f) recovery/performance predictions.

There are several prerequisites for sandstone intrusions to form: the source sediment must be uncemented, and the
\end{abstract}

'parent' sand body must be sealed such that an overpressure with a steep hydraulic gradient can be generated. The seal on the overpressured sand body must then be breached for the sand to fluidize and inject. The stress state within the basin, burial depth, fluid pressure and the nature of the sedimentary host rock all contribute to the final style, geometry and scale of intrusion. At shallow depths, within a few meters of the surface, small irregular intrusions are generated, more commonly forming sills, whereas at greater depth larger and more continuous dikes and sills form clastic intrusion networks. Field examples from the Ordovician in Ireland, and Panoche Hills in California are used to illustrate the control of burial depth/ stress on intrusion scale.

Earthquake induced liquefaction, tectonics stresses and build-up of excess in-situ pore pressure are the most commonly cited explanations for the occurrence of clastic intrusions. However, our work suggests that the largescale, 'catastrophic' sandstone intrusions within the North Sea Paleogene, which remobilized hundreds of cubic meters of sediment, probably require the presence of fluids migrating from deeper within the basin (e.g., gas charge) to drive the injection. Deepwater sand bodies within the North Sea that appear most susceptible to remobilization occur in mud-dominated successions and include (1) narrow, elongate channel or gully-filled sands (i.e., non- 
Remoblization and Injection in Deepwater Depositional Systems: Implications for Reservoir Architecture and Prediction

leveed channel systems), and (2) isolated sand-rich mounds (e.g., 'ponded' sand bodies and terminal fan lobes). Sand bodies located above rift-related basin-forming faults, which periodically appear to have acted as vertical fluid escape pathways, were especially susceptible to remobilization. Sand remobilization may influence reservoir distribution in other mud-dominated, deepwater depositional systems.

\section{Introduction}

Large-scale sandstone remobilization and injection $\left(\mathrm{km}^{3}\right.$-scale) are important components of the deepwater play within the latest Paleocene and early Eocene of the North Sea Basin. These soft-sediment deformation processes have directly affected at least ten significant hydrocarbon accumulations within an area of $\sim 500,000$ $\mathrm{km}^{2}$ in the Central and Northern North Sea (e.g., Forth/ Harding, Alba, Balder, Gryphon fields: Alexander et al., 1993; Jenssen et al., 1993; Newman et al., 1993; Newton and Flanagan, 1993; Timbrell, 1993; Dixon et al., 1995; Lonergan and Cartwright, 1999; Lawrence et al., 1999; MacLeod et al. 1999). Nevertheless, the traditional interpretation of North Sea Tertiary deepwater sandstone bodies is based on the assumption that reservoir distribution and heterogeneity reflect a primary depositional origin. Here is reviewed the mounting body of evidence, which demonstrates that deepwater sandstone geometries can be significantly modified by post-depositional remobilization. An awareness of the processes and products of sandstone remobilization should be incorporated within the current spectrum of deepwater depositional models (e.g., Reading and Richards, 1994), particularly the potential for modifying primary sand body geometries and, in extreme cases, completely controlling reservoir distribution.

We review several seismic-case studies from the North Sea hydrocarbon province, previously unpublished core data and selected outcrop analogues to illustrate the range and scale of clastic remobilization and injection features within deepwater depositional environments. The controls on clastic intrusion formation from a theoretical perspective are also reviewed, and we consider why sandstone intrusion and remobilization are so widespread within the upper Paleogene sedimentary rocks of the North Sea.

\section{Remobilization and its effect on reservoir geology}

Remobilization can be defined as soft-sediment deformation in the sub-surface during early burial, which mainly occurs by the forcible injection of sandy sediments into a fine-grained host-rock. However, we consider the term remobilization as being broad enough to cover a spectrum of processes ranging from the redistribution of sand at its original depositional location (e.g., the sand mounds described by Brooke et al., 1995) through injection, to extrusion of injected sand out onto the sea bed (such as pock-mark craters described by Cole et al., 2000).

As a direct result of remobilization and injection, many North Sea Paleogene reservoirs have more complex geometries than would have been the case if only primary depositional processes had been responsible for their formation. This, coupled with their subtle expression on seismic data and with their lack of primary depositional characteristics (e.g., as seen in core), make the predictability of these deposits difficult, and they remain challenging prospects for exploration and appraisal. For example, sand remobilization processes can result in significant changes to the reservoir geology, as summarized below (Fig. 1):

1. Reservoir architecture (Fig. 1A): Typical features include steepening of original depositional geometries (e.g., Balder Field, Jenssen et al., 1993; Rye-Larsen, 1994); development of pod-like sandbodies (e.g., Balder and Alba Fields); vertical intrusion of clastic dikes and sills above the reservoir (e.g., Forth/Harding, Frigg, Gryphon and Alba Fields; Newman et al. 1993; Newton and Flanagan, 1993; Dixon et al., 1995), and sand intrusion up faults along the reservoir margins (Alba Field, Lonergan and Cartwright, 1999; MacLeod et al., 1999).

2. Reservoir properties (Fig. 1B): Homogenization of sand texture and reservoir properties (e.g., by clay elutriation), and obliteration of original sedimentary structures leading to a massive sandstone facies. These facies are often indistinguishable from originallydeposited massive sandstones, which would be traditionally interpreted as the deposits of either sandy grainflows, debris flows or high-density turbidity currents (e.g., Lowe, 1982; Pickering et al., 1995; Shanmugam et al., 1995; Shanmugam, 2000).

3. Sand body connectivity (Fig. 1C): Clastic intrusions can alter the transmissivity, typically by allowing connectivity between previously isolated reservoir units. However, vertical or steeply dipping dikes, which enable this improved connectivity, will be difficult to image on seismic data. Hence, connectivity between apparently separate sand bodies may not be evident initially, and usually requires dynamic reservoir data (e.g., pressures and/or well test information) to confirm transmissivity.

4. Top reservoir structure/depth surface (Fig. 1D) (e.g., Alba Field, MacLeod et al., 1999): Modifications to the top reservoir surface typically involve a much higher degree of small-scale, 'structural' variability. For example, injection at the top of a parent sand body results in a potentially highly irregular contact between 
it and the overlying injected complex; the previous (pre-remobilization) planar surface at the top sand/ shale interface may be transformed into a surface of small- to medium scale undulations (wavelengths of $\mathrm{c}$. $10 \mathrm{~s}-100 \mathrm{~s} \mathrm{~m}$ ) with associated upward injected dikes and sills.

5. Reservoir volumetrics (Fig. 1D) (e.g., Alba Field, MacLeod et al., 1999; Forth/Harding, Dixon et al., 1995; Balder Field, Jenssen et al., 1993): Injection complexes involving $\mathrm{cm}$ - $\mathrm{dm}$ thick sandstone dikes and sills superficially resemble thin-bedded turbidites (e.g., 'ratty' sands on gamma ray logs). However, sands within injection complexes are much more erratic in their vertical and lateral distribution, they do not display predictable vertical facies successions (e.g., no thickening or thinning upward trends) and lateral trends in sand thickness may be difficult to ascertain. Hence, prediction of net sand volume and recovery efficiency both carry greater uncertainties than in their 'normally bedded' counterparts.

\section{(A) Change in reservoir geometry}
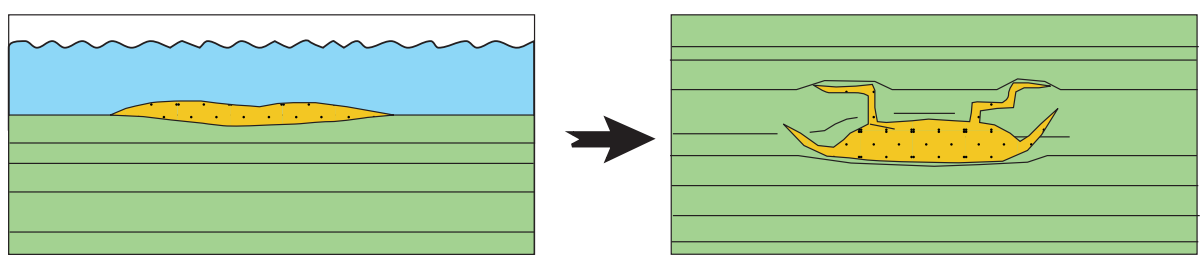

(B) Change in reservoir properties
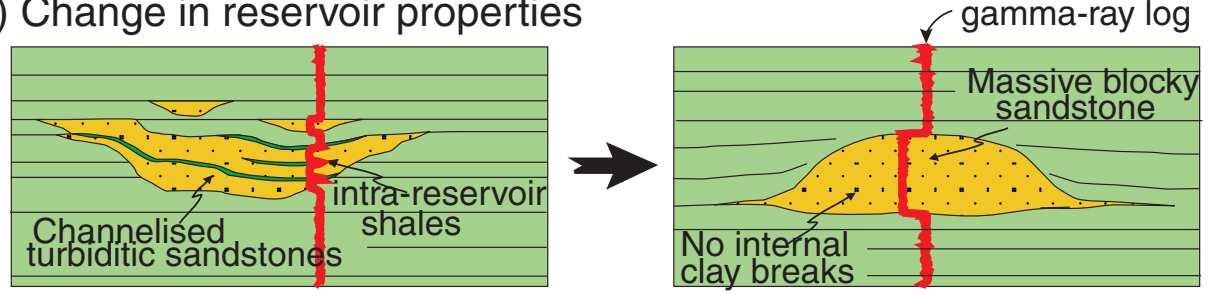

(C) Change in connectivity
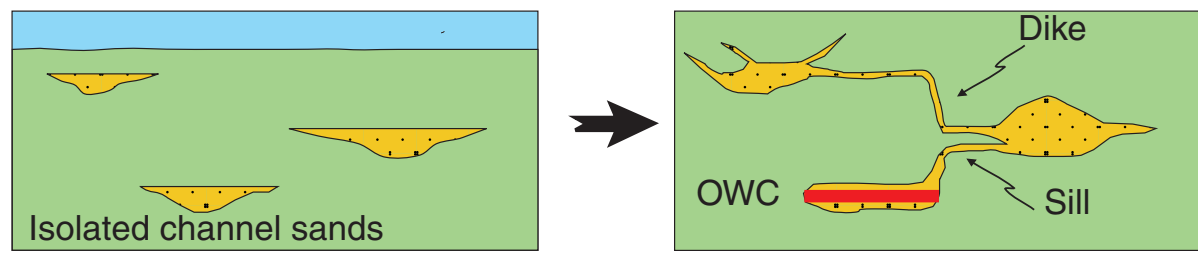

(D) Change in top reservoir surface and in reservoir volumetrics
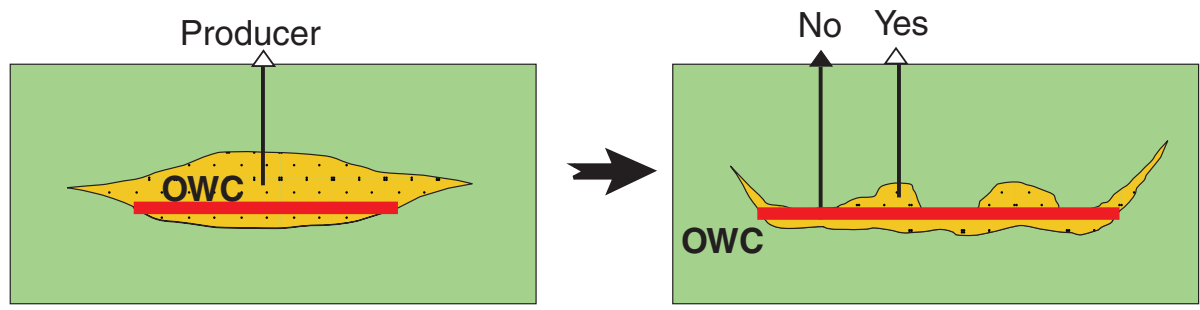

Figure 1. Schematic diagrams illustrating the influence of remobilization and injection on reservoir geology. 
Remoblization and Injection in Deepwater Depositional Systems: Implications for Reservoir Architecture and Prediction

\section{Clastic injection and intrusion triggering mechanisms}

Clastic intrusions are examples of natural hydraulic fractures where a high pressure fluid, flowing at rates capable of entraining sand grains in a liquefied form (i.e., fluidization, Lowe, 1975, 1976; Nichols, 1995) is injected into the surrounding sediments. This process requires firstly a sealed, unlithified, source sand-body, in which an excess-fluid pressure has built up. The seal on the overpressured sand-body must then be breached (suddenly) in order to generate the fluid velocities necessary for fluidization and mobilization of the sediment (Nichols, 1995). A sustained pressure differential between the fluid in the propagating fracture and the fluid in the pores of the sedimentary rock is required, so that the fracture can remain dilated and the sand-fluid mixture can flow through the fracture to form an injection. Once the source of the excess pressure is removed, the remaining fluid in the clastic intrusion will bleed into the surrounding porous sedimentary layers, thereby equilibrating the pressure and terminating fracture propagation. The emplacement of remobilized clastic sediment into the surrounding strata can form sheets of sediment that are either discordant to bedding (dikes) or largely concordant with bedding (sills).

Jolly and Lonergan (in review) reviewed the extensive published literature, spanning a century and more, on the occurrence of clastic dikes and sills. While clastic intrusions have been documented from all depositional environments, they have been most frequently recorded in deepwater depositional settings (Jolly and Lonergan, op cit). Clastic intrusions documented in outcrop are typically small, rarely reaching tens of meters in thickness, but have never been observed at the scale of those interpreted from seismic data in the North Sea. The largest known outcrop examples occur within tectonically active basins, such as the large oil-bearing intrusions exposed near Santa Cruz in California within the Miocene Santa Cruz mudstone, which occur in the Santa Cruz/La Honda strike-slip basin along the San Andreas fault (Thompson et al., 1999). Other large intrusions occur in thrust belt/accretionary prism settings (e.g., Scott, 1966; Winslow, 1983).

Three principal triggers are most commonly invoked for the formation of clastic intrusions (Fig. 2A): (a) tectonic stress (e.g., Winslow, 1983), (b) earthquake induced liquefaction (e.g., Fuller, 1912; Obermeier, 1989), and (c) localized excess pore fluid pressures resulting from depositional processes, such as local loading due to mass movements and slumping (Truswell 1972), the passage of storm waves (Allen 1985; Martel and Gibling, 1993), or channel switching (e.g.,Hiscott, 1979). In general, depositional event triggers tend to produce small-scale $(\mathrm{cm}-\mathrm{m}$ - scale) intrusions dominated by sills (e.g., the Ordovician of Quebec and Western Ireland documented by Hiscott,1979, and Archer, 1984, respectively).

Cyclical shear stresses that occur during shallow focus earthquakes are an effective mechanism for liquefying near-surface water saturated sands, but data from the earthquake engineering literature shows that liquefaction only occurs for earthquakes with magnitudes greater than 5 on the Richter scale (e.g., Ambraseys, 1988; Fig. 2B). Studies of Recent-Pleistocene sediments show that large earthquakes (magnitudes $>6$ ) produce dikes that can occupy fissures $100 \mathrm{~s} \mathrm{~m}$ long in plan view and sand volcanoes up to $40 \mathrm{~m}$ in diameter (Obermeier, 1996). However, even these large events only formed dikes up to $2 \mathrm{~m}$ wide and sills up to $0.5 \mathrm{~m}$ thick, while the dikes only travel at most $10 \mathrm{~m}$ vertically from their source beds (see references cited in Obermeier 1996). Thus, when considering earthquake liquefaction as a potential trigger for clastic intrusion it is important to consider the scale of the intrusion, the depth at which the intrusions formed, and the likelihood that earthquakes greater than magnitude 5 may have occurred at the time of intrusion (i.e., was the basin in an active plate tectonic setting?).

A rarely quoted trigger mechanism is that resulting from external fluid-induced liquefaction. This occurs where the fluid is not the in-situ pore fluid, but migrates into the sealed sand body from elsewhere in the basin. Jenkins (1930) was the first to recognise that the migration of hydrocarbon fluids may have played an important role in the formation of the large number of dikes found in the oilproducing basins of California. Thompson et al. (1999) follow a similar theme in suggesting that the large Yellow Bank Creek intrusion west of Santa Cruz initiated as a fault-related dike, with the horizontal break-out of water saturated sands ahead of a migrating hydrocarbon front increasing both the size and complexity of the intrusion. They also suggest that fluidized sediments may have erupted onto the seafloor in the form of sand volcanoes. In the Central North Sea Brooke et al. (1995) have identified gas-bearing, circular- and mound-shaped sand bodies, that are approximately $1 \mathrm{~km}$ in diameter at depths of $\sim 500 \mathrm{~m}$ beneath the present day sea-bed. These structures appear to be associated with gas conduits. Those authors suggest that upward-migrating gas (possibly along faults) liquefied a laterally-continuous sand body, which contained minor (depositional) irregularities on its top surface. The rapidly migrating gas-saturated fluids with entrained sand grains preferentially flowed towards the subtle highs and generated mounds, with the adjacent low-lying flank areas representing sites of sand withdrawal. 
(A)

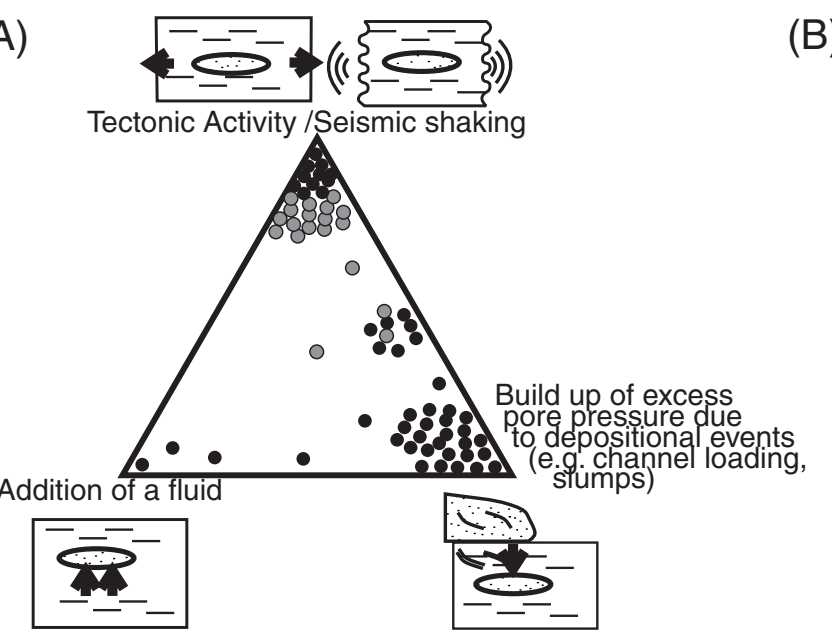

(B)

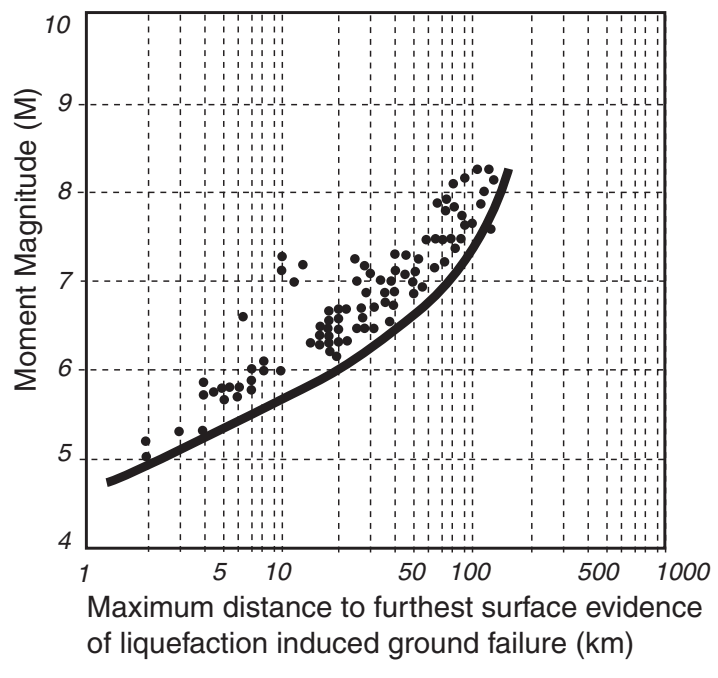

- shallow focus earthquakes

Figure 2. (A) Reported intrusion trigger mechanisms. Dots refer to clastic intrusion localities cited in the literature. (Refer to Jolly and Lonergan for full cited references). Points not located within a cluster at an apice, specify more than one mechanism operating. Grey dots are examples where earthquake induced liquefaction was specifically identified. (B) Liquefaction occurrences according to earthquake magnitudes for historical shallow focus earthquakes. Note the lack of liquefaction for events smaller than magnitude 5 (data from Ambraseys, 1988).

\section{North Sea Case Studies}

\section{Seismic Examples}

The first seismic-scale examples of clastic intrusion described in the North Sea were from the Balder and Forth/Harding fields (Jenssen et al., 1993; Dixon et al., 1995; Fig. 3). The key features of both these examples are (1) isolated and mounded cross-sectional sand-body geometries, (2) circular to oval-shaped plan geometries, (3) rapid sand pinch-out into the shale-prone inter-mound areas, (4) steep sand body margins (up to $15^{\circ}$ ), (5) listric faults detaching at the reservoir level, and (6) possible slumps. Despite initial attempts to apply depositional models to explain these features (e.g., in Balder: Sarg and Skjold, 1982; Hanslien, 1987) they are now widely acknowledged as being part of a closely-related family of remobilization phenomena.

\section{Balder and Forth/Harding}

In the Balder field the km-scale, sub-circular and mounded sand geometries are interpreted as being related to the interaction of several processes (Jenssen et al. 1993), most

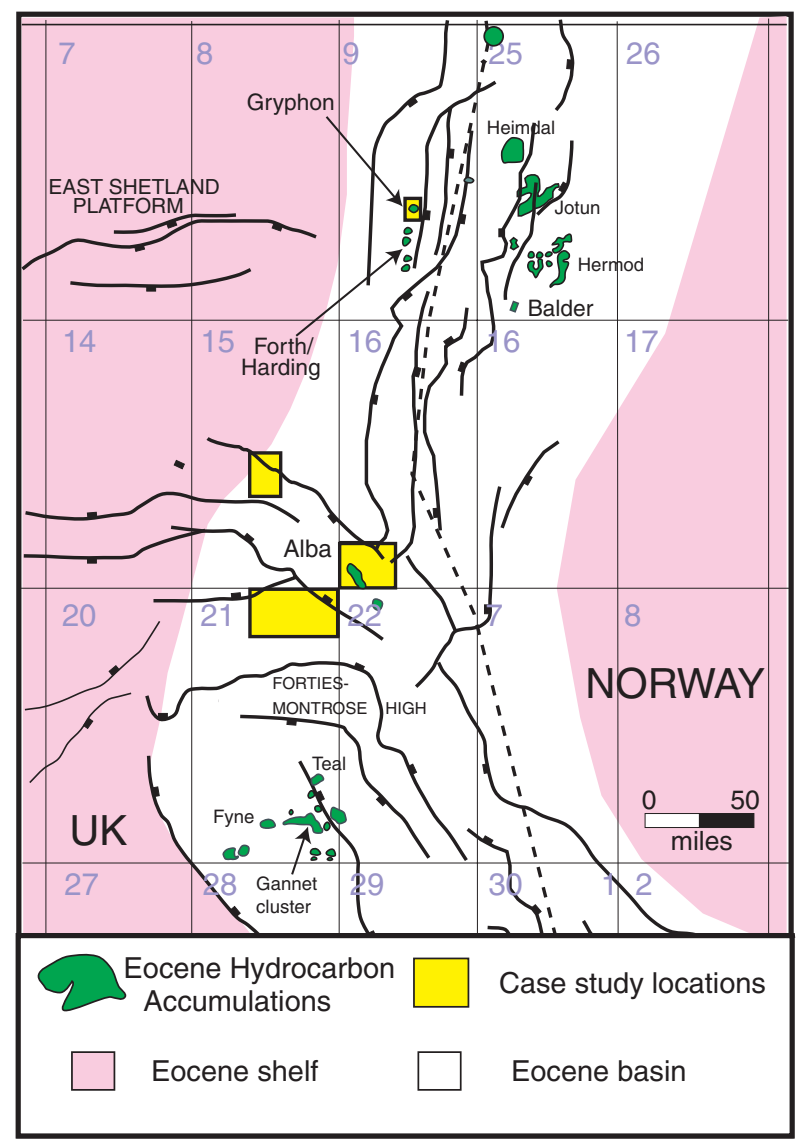

Figure 3. Location of North Sea case studies discussed in text. 
Remoblization and Injection in Deepwater Depositional Systems: Implications for Reservoir Architecture and Prediction

notably (1) initial deposition (late Paleocene/early Eocene) of massive sands by high-density turbidity currents in the form of broad, low-relief, submarine fan lobes, located near the depositional end of a channelized submarine-fan complex, (2) top seal provided by hemipelagic mudstones, which draped the underlying fan lobe topography, (3) faulting and sliding of the deeper Paleocene section down the dipping Top Chalk surface, (4) liquefaction and fluidization of the unconsolidated fan lobe sands, and (5) breaching and injection of the uppermost sands (Balder Formation) into the top seal mudstones during the early Eocene. Once the seal was breached, a pressure differential was generated in the Balder sands and the sands flowed from one area to another, probablyexploiting the original depositional topography and generating new, injection-related mounded geometries, with localized sand volcanoes and smaller-scale dike and sill complexes in the overlying mudstones (as reconconstructed from core observations).

In the Forth/Harding field large-scale sandstone intrusions are inferred where high-amplitude reflections cut across the Balder reflector (Dixon et al., 1995). On timeslices, the injected sands are cuspate in plan view and continuous for $500 \mathrm{~m}$, leading to the suggestion that the sands were injected into listric faults. The largest seismic example of a clastic intrusion in the North Sea has been documented by Lawrence et al. (1999) from Block 24/9 of the Norwegian North Sea, where a km-scale sandstone dike cross-cuts some $200 \mathrm{~m}$ of stratigraphy.

\section{The Alba Field}

Recently Lonergan and Cartwright (1999) documented how the narrow (ca. $1.5 \mathrm{~km}$ ), elongate (ca. $12 \mathrm{~km}$ long) geometry and shape of the Eocene Alba Field in Block 16/ 26 of the Central North Sea has been significantly modified by polygonal faulting in the surrounding mudstones and by closely-associated sandstone remobilization. Polygonal faults are early, compaction-related normal faults that form within layer-bound stratigraphic units, and are widespread throughout the deepwater Paleogene successions of the North Sea (Cartwright and Lonergan, 1996; Lonergan et al., 1998; Dewhurst et al., 1999). Depositional processes are believed to have been responsible for the dominantly linear shape and channelized cross-sectional geometry of the main reservoir (Newton and
Flanagan, 1993). However, close observation shows that the current reservoir geometry is also influenced by the location of a network of polygonal faults in the surrounding basinal mudstones. Sheets of injected sandstone occur along faulted margins of the Alba field ("wing" structures, Fig. 4A) and follow the trend of the polygonal fault system. This indicates that polygonal faulting facilitated remobilization and sand injection during early burial, which resulted in both modification of the primary reservoir geometry and redistribution of reservoir sands. The latter is illustrated by an overlying injection complex and by adjacent, mounded sand bodies. For example, isolated, $1 \mathrm{~km}$ wide, sub-circular mounds to the west of the main field are attributed to sand withdrawal and remobilization during early burial (Fig. 4B). Recently, Chevron and partners have acquired a new 3-D survey over the Alba field using four-component ocean-bottom-cable technology which has enabled the top reservoir to be imaged seismically for the first time. These data highlight more examples of high amplitude "wing" structures along the reservoir margins and occasionally over the central axis of the field (McLeod et al., 1999). Two recent wells have verified that the "wings" visible on seismic data are injected sands, with one of these injections comprising a $20 \mathrm{~m}$ thick sand layer (McLeod et al., 1999).

\section{Conical Intrusions in Quadrants 16 and 21}

Kilometer-scale, low-angle, cone-shaped seismic amplitude anomalies have been mapped within the lower Eocene succession on 3D seismic datasets covering Quadrants 16 and 21 of the Outer Moray Firth area in the North Sea (Fig. 3). S. Molyneux, J. Cartwright and L. Lonergan (pers. comm.1999) interpret these features as large-scale clastic intrusions, sourced from deepwater sands that have intruded along the associated and extensive network of polygonal faults. The cone features typically have Vshaped, high seismic amplitude anomalies when viewed in cross-section (Fig. 5), which resemble the "wings" observed in the Alba field. They are circular to sub-circular in plan, with diameters ranging from 0.5 to $2 \mathrm{~km}$. The amplitude anomalies defining the cones cross $100-300 \mathrm{~m}$ of stratigraphy and dip at angles of $5-25^{\circ}$ (uncorrected for compaction) outwards from the basal apice of the " $\mathrm{V}$ " or cone. Comparisons between the plan geometry of the 

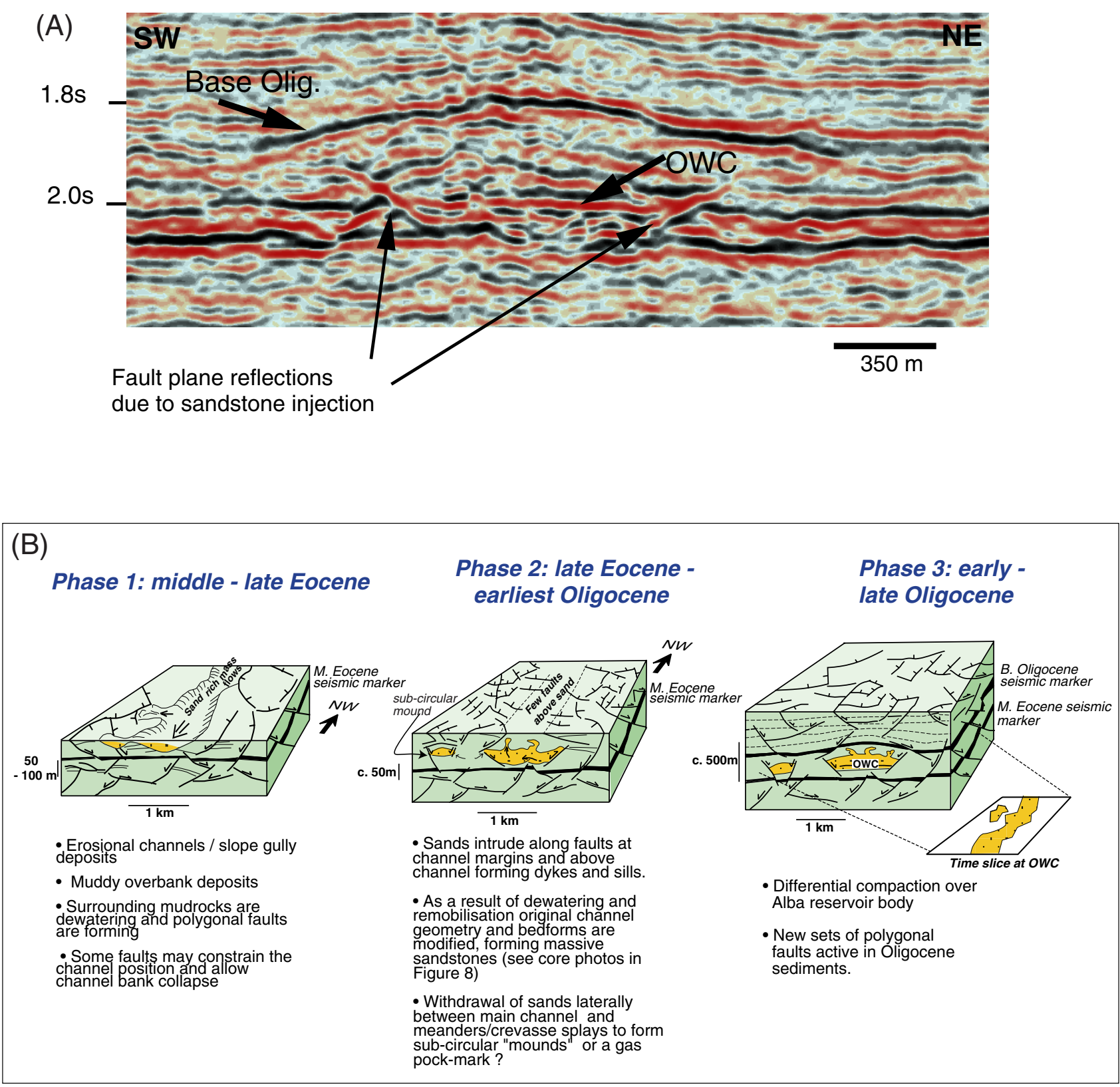

Figure 4.(A) A seismic section from the 1989 3-D seismic survey over the Alba Field showing high amplitude "wings" interpreted as sandstone injected up faults on the margins of the field. (B) Model for the deposition and subsequent modification of the Alba reservoir (see Lonergan and Cartwright, 1999 for more details).

polygonal fault system in the same datasets, and timeslices through the conical anomalies, shows that they possess the same spatial organization and plan geometry. Well 21/5b-1 was used to calibrate the seismic amplitude anomaly, using gamma-ray and sonic logs. The amplitude anomaly corresponds to a 'blocky,' $20 \mathrm{~m}$ thick, structureless sandstone (S. Molyneux, J. Cartwright, L. Lonergan pers. comm. 1999). Although these cones superficially resemble deep-water channel bodies in cross-section, their spatial organisation in plan view precludes such an inter- pretation. Instead, it is proposed that the cones are largescale sandstone injections that have intruded into surrounding claystone formations, exploiting pre-existing low-angle polygonal fault networks.

\section{Gas Pockmark Craters in Quadrant 15}

The final example of large-scale sand remobilization are the early Eocene gas pockmarks described by Cole et al. (2000) from Quadrant 15, of the central North Sea 

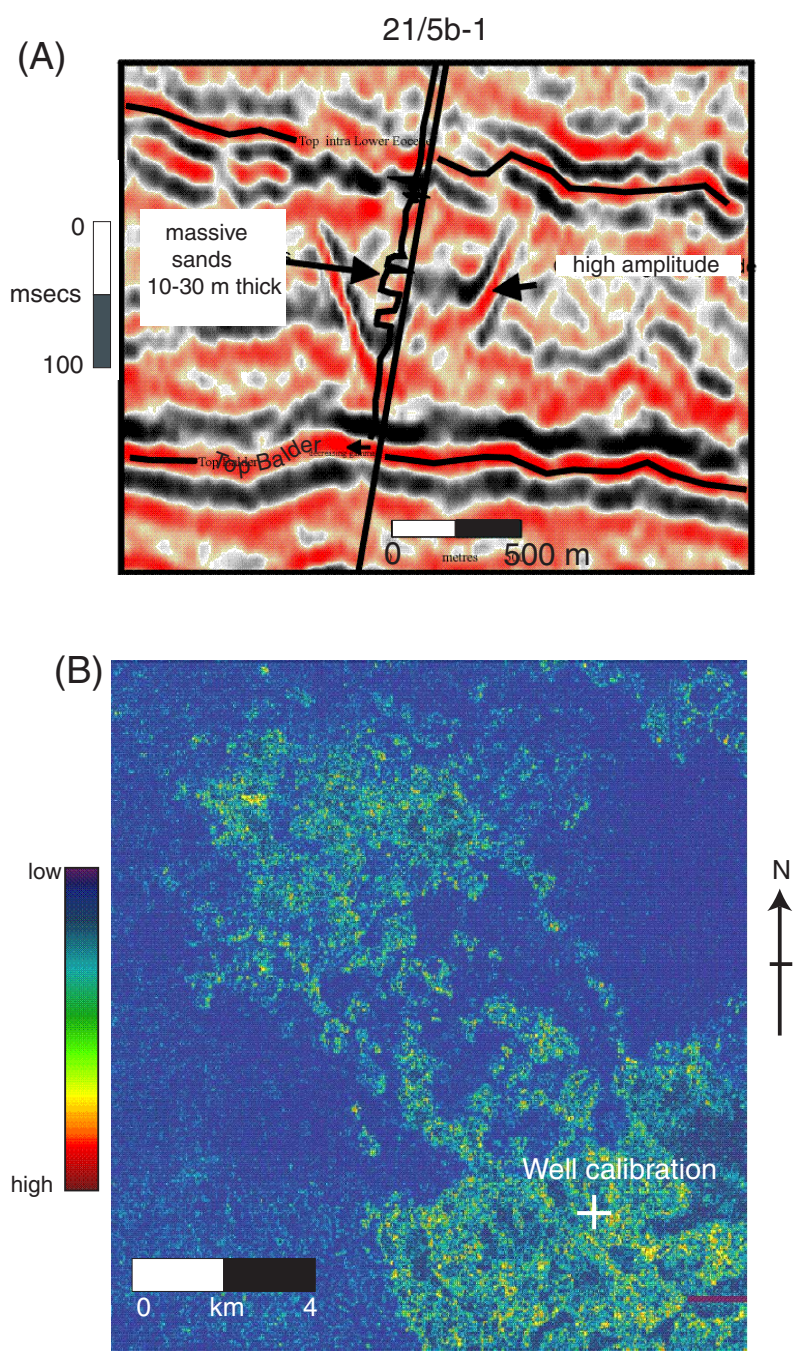

Figure 5. (A) Seismic section through a lower Eocene conical intrusion in Quadrant 21, North Sea. Note section is highly squeezed exaggerating the dips on the cone margins; Well 21/ 5b-1 and gamma-ray log used to calibrate the seismic amplitude are also shown. (B) Seismic amplitude map, where the maximum amplitude has been extracted from a lower Eocene stratigraphic window that includes the cone-like structures (pers. comm. S. Molyneux, J. Cartwright and L. Lonergan, 1999.

(Fig. 3). These comprise a cluster of circular and irregular 'crater-like' structures that range from 0.5 to $4 \mathrm{~km}$ in diameter, occurring just above the Balder Tuff level (Paleocene/Eocene boundary), which Cole et al. (2000) interpret as buried gas pockmark craters that were filled with sand (Fig. 6). On seismic data these features display horizontal to sub-horizontal bases with mounded upper sur- faces (Fig. 6A), while internally they are seismically chaotic. Well penetration of one structure (H, on Fig. 6B) encountered an infill of very fine-fine grained, moderately well sorted sand, that was partially cemented with calcite, with an overlying $130 \mathrm{~m}$ thick mudstone succession. Cole et al. (2000) suggest that these features formed due to gasinduced cratering. Gas accumulated in a shallow reservoir sealed by the Balder Formation claystones. Subsequent gas leakage into the reservoir caused overpressuring and doming of the seafloor. Top seal failure resulted in catastrophic fluid escape and instantaneous fluidization of the overlying sediment, and the coarser, sand-grade component of the fluidised sediment volume collapsed back into the crater, while fines were placed in suspension and transported to other parts of the basin. This model is similar to that proposed for the formation of pockmarks on the seafloor at the present day (Hovland and Judd, 1988). From at least two view points the discovery of these pock-mark craters is important. Firstly, as stated by Cole et al. (2000), the approximate gross rock volume calculated for these features (ca. $\sim 100 \times 10^{6} \mathrm{~m}^{3}$, Cole, 1998), the nature of the infill (clean, massive sands) and their development within the proven productive early Eocene interval in the North Sea suggests that such features could represent potential targets for future hydrocarbon exploration. Secondly, their presence would confirm that significant volumes of gas were being generated and vented during the early Eocene, producing large "blow-outs" on the basin-floor. The regional implications of this will be discussed later.

\section{Core Examples}

The Alba, Balder, Gryphon, and Forth/Harding reservoirs (Fig. 3) are all characterised by the presence of extensive injection complexes overlying the main reservoir sand, as observed in core. Some of the key features of the injected intervals include the following: (1) complex sill and dike geometries, resembling features generated by dilation, stoping and brecciation during intrusion; (2) abundant angular inclusions of the host mudstones, suggesting host-sediment cohesivity at the time of injection; (3) margins of these intrusions are nearly always sharp, indicating host-sediment cohesivity/fast flow velocities during injection; (4) dikes are frequently ptygmatically folded, suggesting that injection occurred early within the burial history before significant compaction; and (5) intrusions are often oil-bearing or, more rarely, calcite cemented. All of the above features are illustrated in the core photographs of the Gryphon field, Quadrant 9 of the North Sea (Fig. 7). 


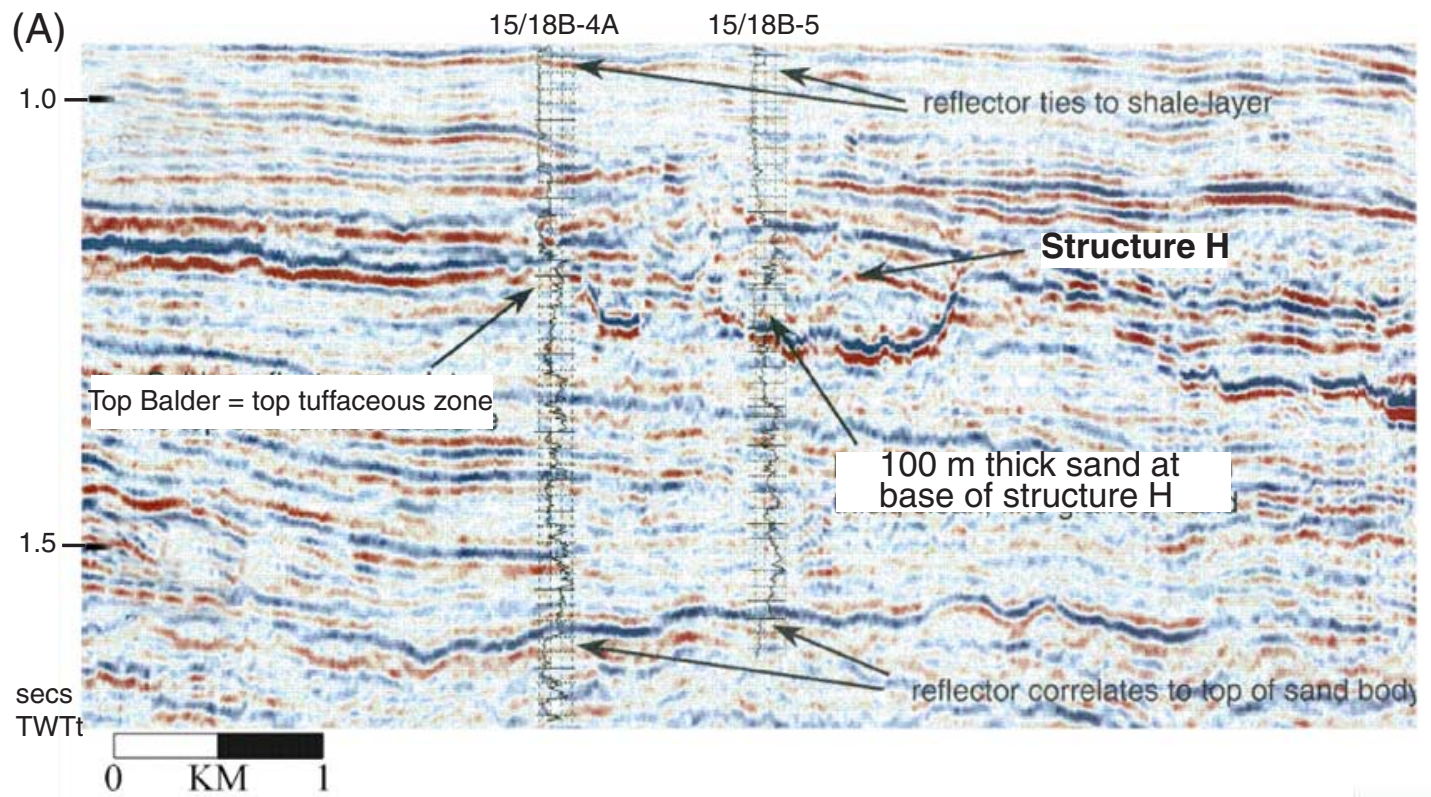

(B)

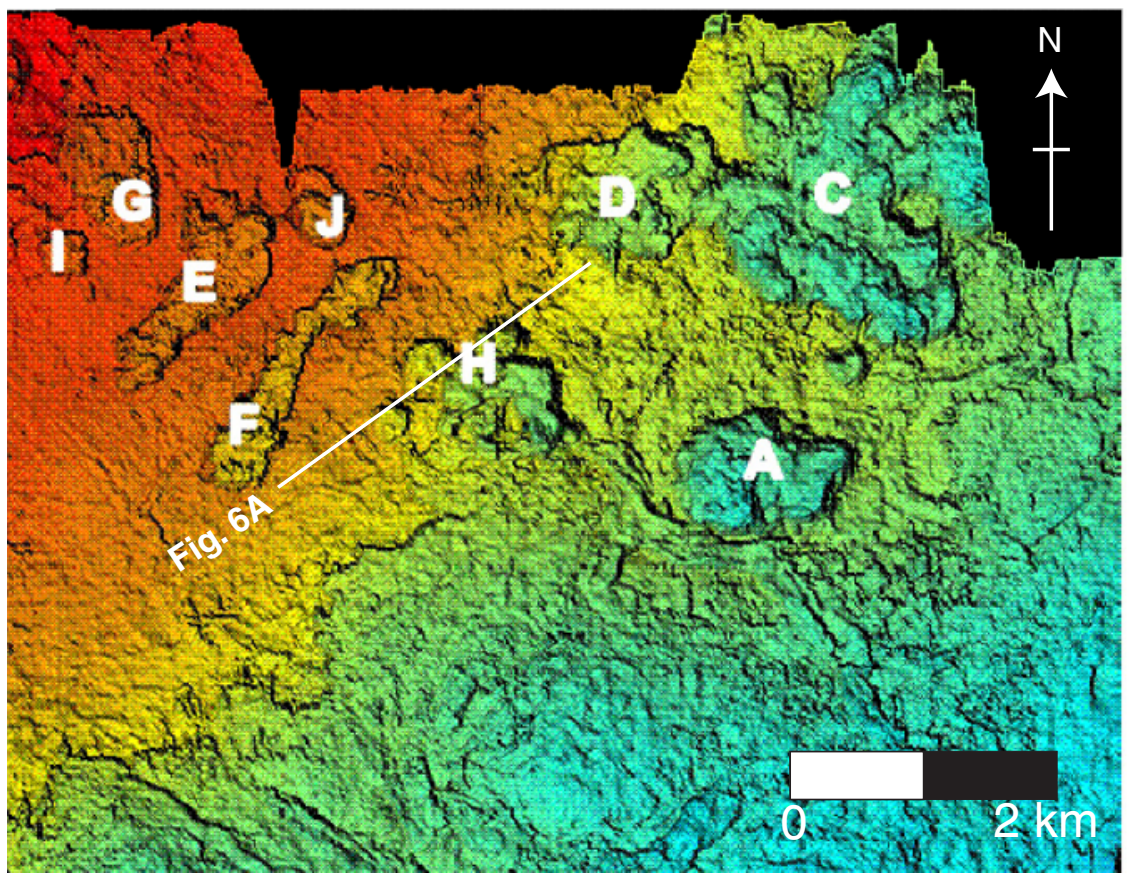

Map of Top Balder; travel time range is $1100-1500$ ms; reds lower values.

Figure 6. (A) Seismic section through "structure $H$ " interpreted as an Eocene, sea-bed gas pock mark, with seismic to gamma ray log correlation for wells $15 / 18 b-4$ and $15 / 18 b-5$. (B) Artificially shaded color two-way travel time contour image of the top Balder Formation on which a number of pock marks can be identified (labelled A-H). Time-structure contours cover an interval of 200ms TWTt; the surface dips from NW to SE (from Cole 1998, by permission of author). 

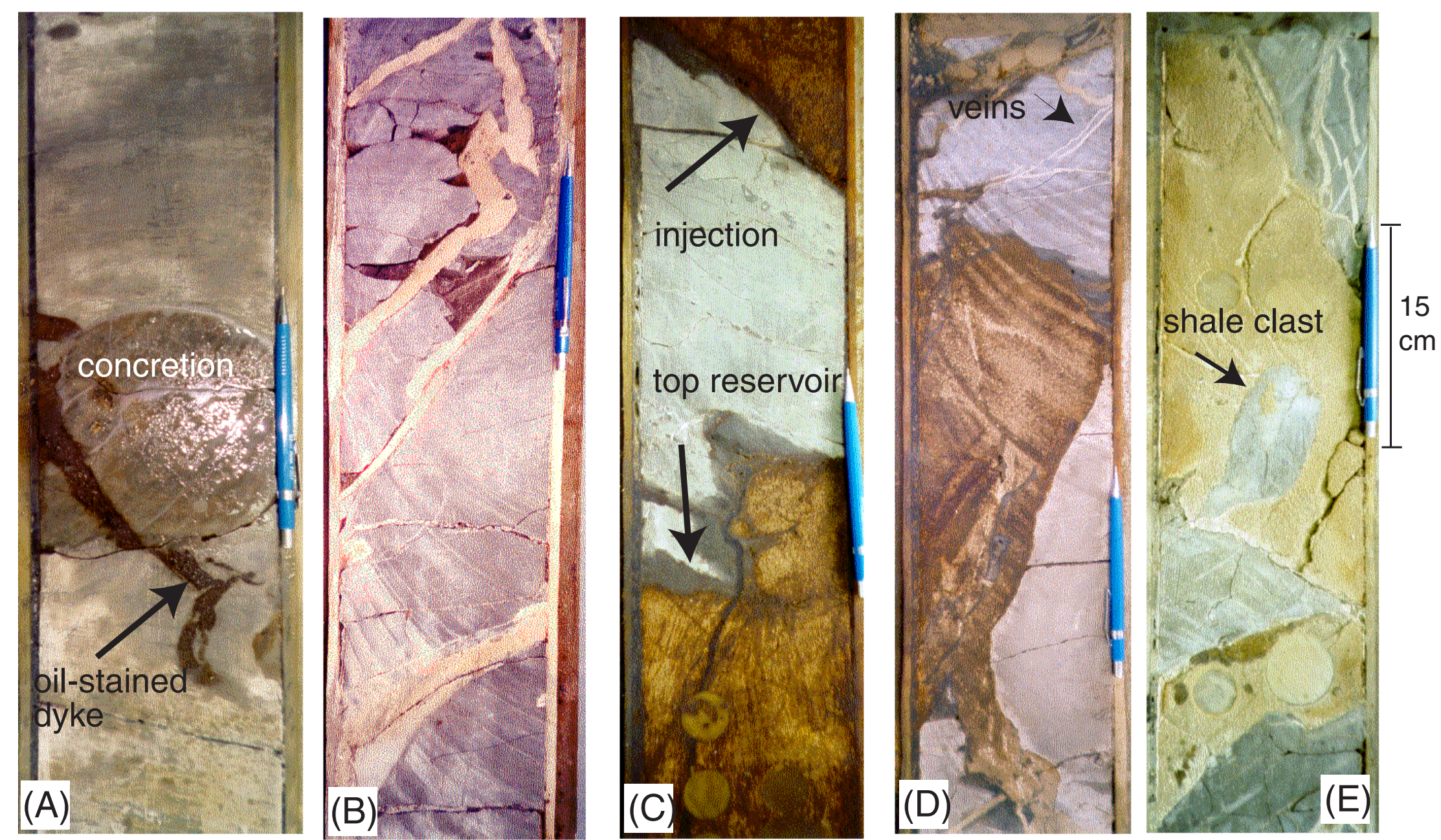

Figure 7. Core photographs from the Gryphon field. (A) Oil-stained dike cross-cutting an early carbonate concretion; (B) carbonate cemented dikes, note ptygmatically folded dike; (C) lower sand-shale contact is the deformed top reservoir; upper dipping contact is a clastic intrusion; (D) irregular-shaped oil-stained injection with sharp margins; Small calcite veins are present in the host mudrocks; (E) sandstone injection with angular clasts of the host shale. 


\section{Alba Field}

Core from the Alba field exhibits similar features to those found in Gryphon core. The cored interval in Figure 8A is an oil-bearing, sandstone injection complex above the main reservoir unit. Note the sub-parallel, sharp top and bottoms of dikes (x), ptygmatic folding indicating plasticity of the host sediments during intrusion (y), and the stockwork of intimately associated angular clasts of host muds and intruded sand (z), indicating explosive brecciation during intrusion. Despite the chaotic nature of the intrusive complex, the oil staining illustrates its connectivity with the main reservoir beneath. In contrast, Figure $8 \mathrm{~B}$ illustrates a $3 \mathrm{~m}$ cored section through the main Alba field reservoir. The homogeneity and lack of bedding structures within the sands is most striking; the only sedimentary structures visible are subtle dewatering-related dish structures. This is one of the most typical reservoir facies encountered in the Late Paleocene- Early Eocene reservoirs in the Central and Northern North Sea.

\section{Mechanics of Clastic Sill and Dike Formation}

Intrusion of a clastic dike or sill requires that the host rock fails in the brittle regime, and that a fracture propagates which is filled with injecting sediment. A propagating dike (whether of igneous or clastic origin) is considered an example of an opening mode (mode I) fracture that propagates as a tensile crack in a plane normal to the least compressive stress direction (e.g., Delaney et al., 1986). For mode I failure, the host rock must have tensile strength. Cohesion of the host rock is, therefore, critical if clastic intrusions are to form. In the simplest of cases- a basin that is not subjected to any applied tectonic stressesthe maximum compressive stress is vertical (due to the weight of the sediments) and for a dike to propagate the fluid pressure $\left(P_{f}\right)$ must exceed the horizontal stress $\left(\sigma_{h}\right)$ and the tensile strength of the host sediment parallel to the bedding $\left(T_{h}\right)$ (e.g., Delaney et al., 1986; Price and Cosgrove, 1990; Chapt.3),

$$
P_{f}>\sigma_{h}+T_{h}
$$

For a sill to form the fluid pressure must exceed the vertical stress $\left(\sigma_{v}\right)$ and the tensile strength perpendicular to the bedding $\left(\mathrm{T}_{\mathrm{v}}\right)$ (Price and Cosgrove, 1990):

$$
P_{f}>\sigma_{v}+T_{v}
$$

Pressure data from boreholes and reservoirs in most sedimentary basins world wide, show that rock fails before the pore fluid pressure reaches the lithostatic or overbur- den pressure (in this example $\sigma_{v}$ ). Typically a rock fractures at values of 0.7-0.8 $\sigma_{v}$ (Lorenz et al., 1991). This implies that when a seal trapping an overpressured sand body fails by fracture, sills will not form, because the fluid pressure is less than the vertical stress and tensile strength of the sediments/rocks combined. Or put another way, the vertical stress is larger than the horizontal stress and it is easier for failure to occur perpendicular to the direction of the minimum horizontal compressive stress, $\sigma_{h}$. Therefore, when the seal fails, initially a dike is more likely to form. Because the dike propagates upwards, there is a decrease in depth with a relatively small decrease in the fluid pressure associated with the propagating intrusion. In the case of a faster rate of reduction of the vertical stress than fluid pressure, a point will be reached shallower in the section where the fluid pressure will exceed the vertical stress. At this point equation (2) is satisfied and the dike will turn into a sill. For this to occur there has to be a significant initial fluid pressure head. If not, and the fluid pressure dissipates rapidly, the intrusion will 'freeze' as a dike before it ever gets shallow enough to form a sill.

At very shallow burial depths, within a few meters of the surface, differential stresses are typically low (the overburden stress, $\sigma_{v}$, is very small and likely approaches the magnitude of the minimum horizontal stress, $\sigma_{h}$ ). In this case, the differential stress may not be significantly greater than the differential tensile strength and the bedding /fabric anisotropy will favour the formation sills as it will be more difficult for a dike to propagate against the anisotropy:

$$
\sigma_{v}-\sigma_{h}<T_{H}-T_{V}
$$

\section{Burial Depth and Intrusion Scale}

During Paleogene times, the North Sea Basin, was in its post-rift infill stage, and sediments were being deposited and accumulating in the basin in a tectonically rather passive environment, where the maximum compressive stress was likely to have been vertical. Next the effects of burial depth on intrusion scale for this simple setting are considered. The discussion is restricted to shallow burial depths (e.g., first $1 \mathrm{~km}$ ) where clastic sediments compact largely by consolidation, with minor cementation or pressure solution. If we assume that the source of the fluid in a sand body, that undergoes fluidization and injection is the original pore fluid, then a sealed sand that is breached at very shallow depths is likely to form a compact sill and dike complex. If, for instance, the sand body becomes sealed at point $a$ on the graph in Figure 9, and no more fluid enters the sand body, the fluid pressure within the sand body deviates from the hydrostatic gradient and will 

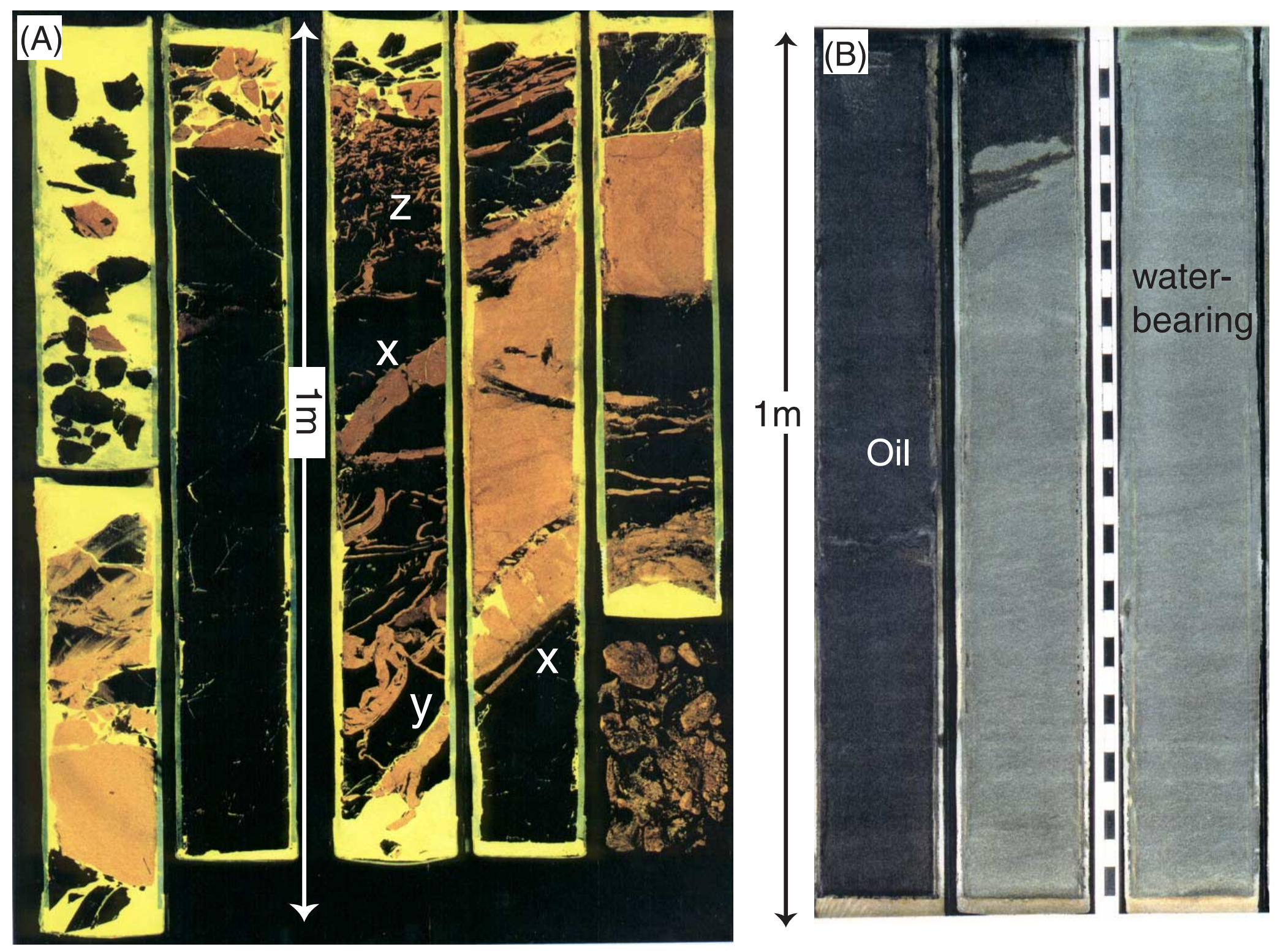

Figure 8. Core photographs of the Alba reservoir (A) Oil-bearing, sandstone injection complex above the main reservoir (Photograph taken in ultra-violet light; oil bearing sands fluoresce, shales are black); $x=$ sub-parallel, sharp sided dikes; $y=$ ptygmatic dikes; $z=$ brecciated, stockwork texture. (B) Massive sandstone facies of the کू. main reservoir; note subtle dish structures. 


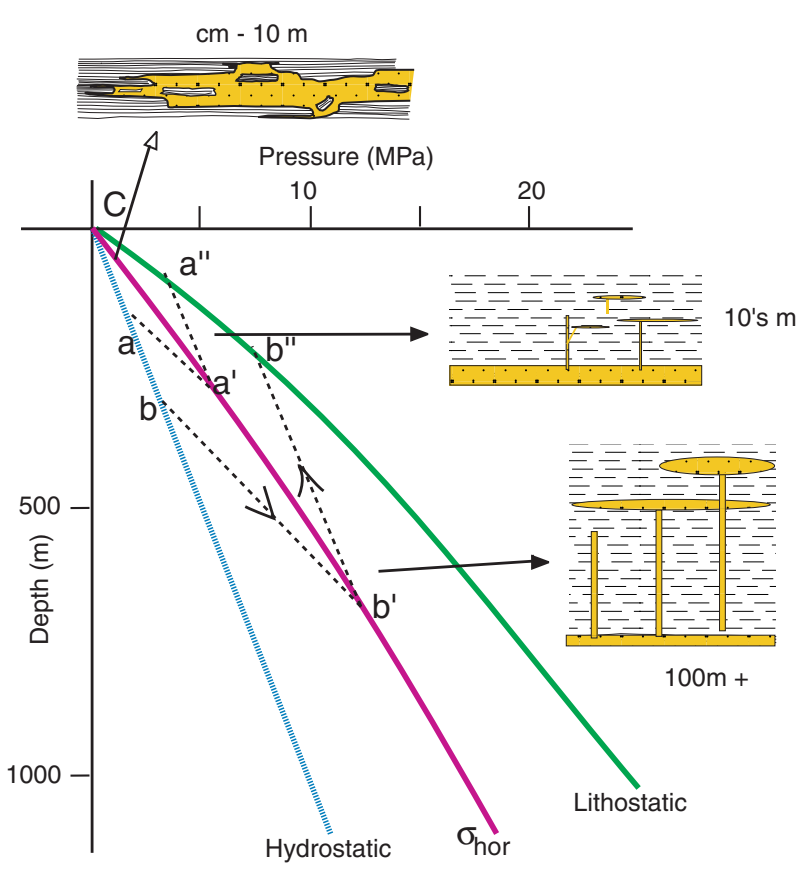

Figure 9. Simple model illustrating how the scale of clastic intrusion comples is a function of the depth of seal onset and depth at which the seal ruptures. Note,only valid for a basin where the maximum principal stress is vertical (gravitational loading).

increase at the same rate as the lithostatic gradient as it is buried. Once the fluid pressure reaches the minimum horizontal stress (point $a$,' Fig. 9), the seal fails and a dike starts to form. Assuming that there is a large enough reservoir of overpressured fluid the dike will continue to propagate until the fluid pressure equals the maximum vertical stress and a sill will form (point $a$,', Fig. 9). Because of the small, initial pressure differential the dike will only propagate a small distance vertically before a sill develops (see path $a, a$,' $a$ "' on Fig. 9). At these shallow depths as discussed above, bedding anisotropy is also likely to favour the development of sills. The limiting case is where the source sand body is small with only a small amount of sealed fluid, restricting the amount of sand that can be mobilised before the pressure dissipates, and fluid pressure drops, freezing the intrusion.

Next, the case where a sand body is sealed a bit deeper, but the seal is not breached until greater burial depths is considered (path $b, b^{\prime}$ on Fig. 9). In this instance a greater pressure differential is established, higher flow rates ensue, and a larger volume of sediment can be fluidised. Obviously thicker and larger volume clastic intrusions can form. Because of the greater depth of initiation the dikes will propagate further before the fluid pressure exceeds the maximum overburden pressure and a sill forms (path $b^{\text {'- }}$ $b$,' Fig. 9). The depth of failure, therefore, produces distinctive styles of intrusion, with very shallow failure favouring the development of compact dike and sill complexes, dominated by sills. Jolly and Lonergan (in review) develop these arguments further and derive some simple relationships for calculating the height at which a dike will turn into a sill, or if the dike height is known, what depth failure occurred, in cases where the ratio of the vertical and horizontal effective stresses is known for the basin, and sediment densities can be estimated.

In Figure 10 two field examples of dike and sill complexes which formed at different ends of the depth/ differential stress spectrum are shown. A Cretaceous dike and sill complex exposed in the Moreno Formation of the Panoche Hills in the San Joaquin valley, California (Fig. 10A) represents an example of trajectory $b-b{ }^{\prime}-b$ " in Figure 9. The exposed cliff section is about $80 \mathrm{~m}$ high and the main sill is at least $80 \mathrm{~m}$ above the source sand. In comparison Figure 10B, shows a metre-scale sill-dominated clastic intrusion from Ordovician deepwater sedimentary rocks on the Rosroe Peninsula in Western Ireland, which formed at very shallow burial depths and was triggered by depositional events.

\section{Faulting and Intrusion Geometry}

The simple theory outlined above for the formation of dikes requires some modification if intrusions occur into a host rock that contains pre-existing faults or fractures. As already discussed, vertical dikes should be the first type of intrusion formed when a seal fails. However, where there are pre-existing faults or fractures within the host sediment, the pore fluid pressure $\left(P_{f}\right)$ need only exceed the resolved normal stress $\left(\sigma_{n}\right)$ across the fracture for dilation to occur:

$$
P_{f}>\sigma_{n}
$$

where the normal stress $\left(\sigma_{n}\right)$ is less than the horizontal stress $\left(\sigma_{h}\right)$ and the tensile strength of the host sediment. Under these circumstances non-vertical dikes will form intruding along fracture planes (Fig. 11A). As the fluid pressure increases a larger range in fracture orientations will be able to dilate and be intruded by the injecting sands (Delaney et al. 1986; Baer et al., 1994; Jolly and Sanderson, 1995). The photograph in Figure 11B illustrates this mechanism: two oblique dikes intruding flat-lying Miocene Santa Cruz siliceous mudstones. The dikes dip at $\sim 60^{\circ}$ and intrude along a set of pre-existing shear fractures within the mudstones. The "wings" on the margins of the Alba reservoir and the conical dike swarms in quadrants 16 and 21, which injected along the polygonal fault networks in the surrounding mudstones, are also a manifestation of this mechanism at a larger scale. When the sand was fluidised and injected it was mechanically 


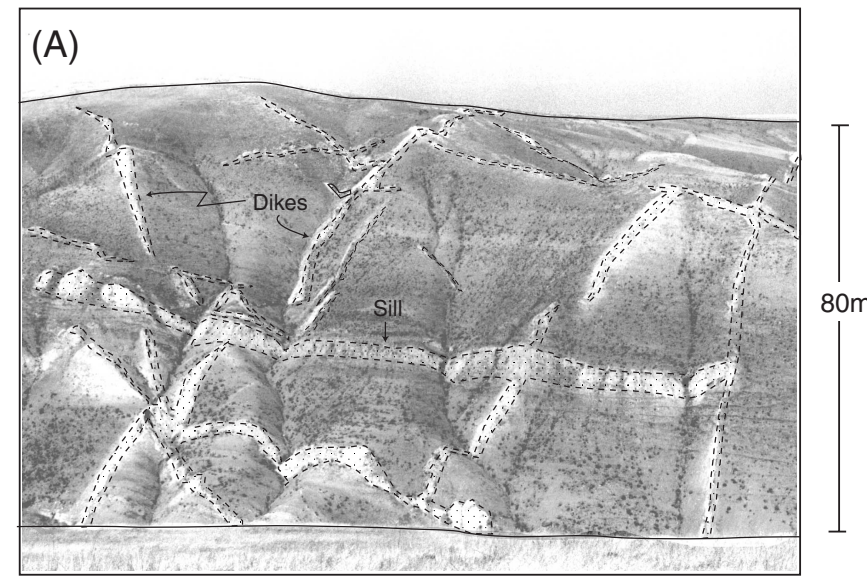

(B)

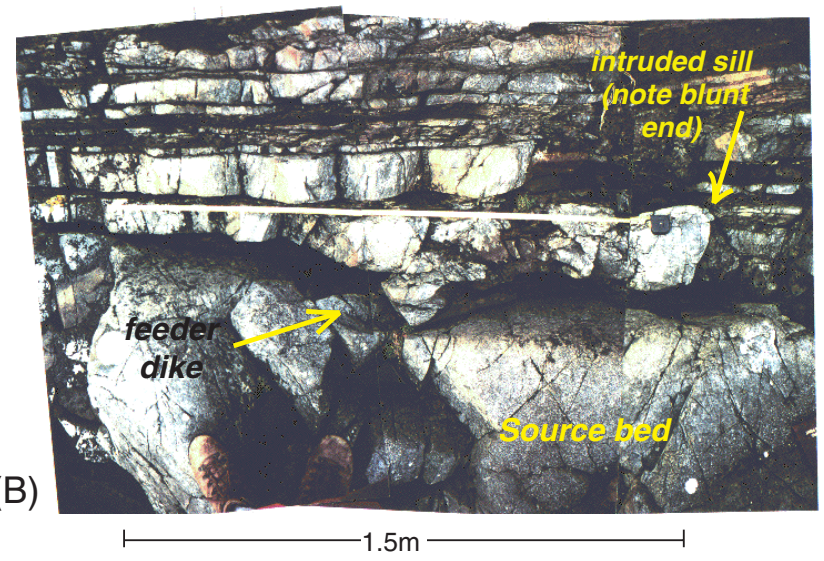

Figure 10. Two different clastic intrusions that formed at opposite ends of the burial-depth spectrum. (A) Photograph of a hillside in the Panoche Hills, western margin of the San Joaquin Basin, California. Sandstone from the Upper Cretaceous Moreno Formation intrudes overlying shales of the same formation. Cliff is $\sim 80 \mathrm{~m}$ high; source bed is ca. $80 \mathrm{~m}$ below main sill in center of photograph. Example of trajectory $b-b$ ' $b$ "' in Figure 9. Refer to Smyers and Peterson, (1971) and McGuire, (1988) for more information on the geological setting of these intrusions. (B) An example of a small sill, very short feeder dike and source bed, from the Ordovician Rosroe Formation, Rosroe, western Ireland, formed at C (very near surface) in Figure 9. more efficient to dilate existing faults, than to make new vertical dikes.

\section{Discussion}

When considering the formation of very large clastic intrusions that are hundreds of meters in size, it will be easiest to remoblise large volumes of sand under conditions of significant applied tectonic stresses (e.g., fold and thrust belts, accretionary prisms, or strike-slip basins), resulting in high differential stresses. Otherwise, for a basin where the maximum stress is the vertical overburden pressure, the sand body will have to be sealed early, when it has high porosity, and buried deep enough (>1 km?) to allow a high enough overpressure to build up that will fluidise large volumes of sand when its seal is breached (e.g., Fig. 9). In order to inject large volumes of sand the flow would have to be sustained for a significant period of time. For the cubic-kilometer scale North Sea intrusions, it is very difficult to appeal to high tectonic stresses as the causal mechanism for sand remobilization. By late Cretaceous times the North Sea was no longer actively rifting and was subsiding in its post-rift thermal phase. Aside from localized salt-domes that continued to be active throughout the Tertiary, there was no significant active tectonic faulting affecting the basin. The lack of major Tertiary faults also suggests that there was no large magnitude seismicity ( $>$ magnitude 5 ) in the region. However it is the large-scale of the intrusions, two orders of magnitude bigger than the scale of intrusion observed even after the most severe magnitude 7 historical earthquakes, that really precludes earthquake-triggered liquefaction as a mechanism for the large-scale late Palaeocene-early Eocene remobilization in the North Sea. 

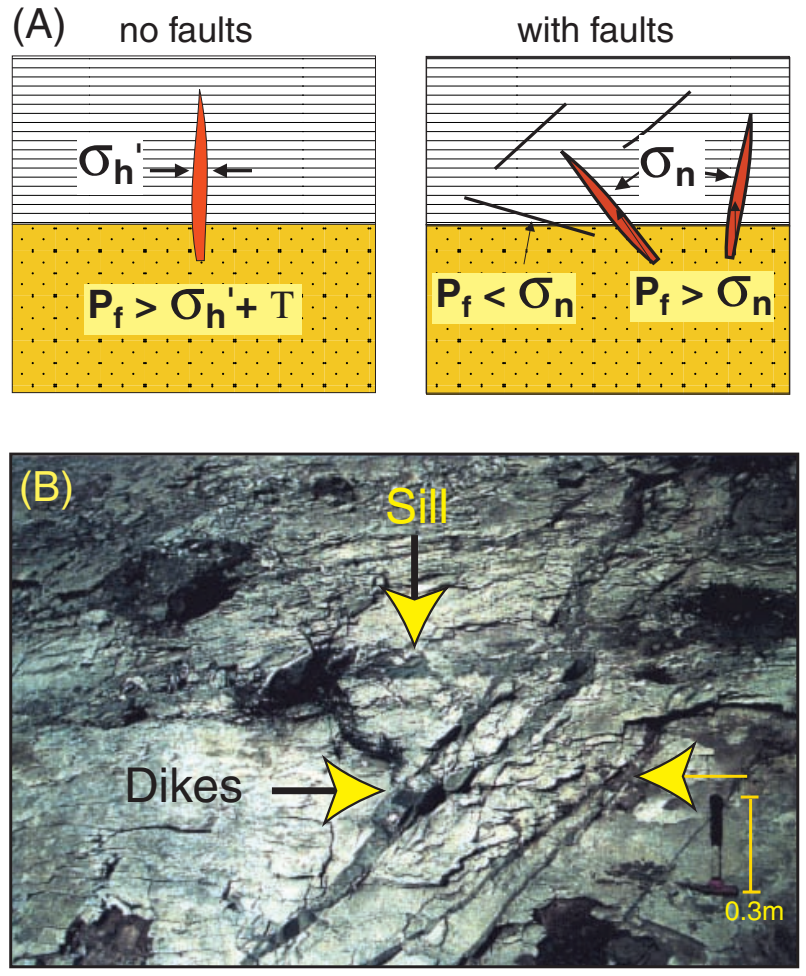

Figure 11. (A) The effect of faulting on dike orientation. (B) Two dikes intruding shear fractures within the Miocene Santa Cruz mudstone, near Santa Cruz, California. Hammer for scale is $30 \mathrm{~cm}$ long.

Another mechanism, however, that would be very effective in mobilising large volumes of sand is the addition of another fluid, such as migrating hydrocarbons, into the sealed system (as suggested by Jenkins, 1930 and Brooke et al., 1995). Gas that entered a sealed sand could generate high pore-fluid pressures at much shallower depths, than if the original interstitial pore fluids were trapped as shown by trajectory b-b'-b" in Figure 9. In a North Sea context, maturity modelling studies have shown that the main source rock (within the Jurassic Kimmeridge Clay Formation) was actively generating hydrocarbons in the deepest parts of the central and northern North Sea basin during the Paleogene providing a fluid charge to the basin (e.g., Cornford, 1998; Johnson and Fisher, 1998). It seems highly plausible that the high fluid pressures required to remobilize the large volumes of intrusive North Sea sands came from hydrocarbon fluids and water migrating to shallow levels, via salt structures and compaction faults over tilted normal fault blocks. Once the buoyant gas or oil entered isolated sand bodies with relatively weak mudstone seals there would be enough fluid pressure to rupture the seal, remobilize and inject large volumes of sand. The identification of Eocene-age gas pock-mark craters in the central North Sea (Fig. 6; Cole et al., 2000) testifies to the fact that this is a viable mecha- nism, and proves that large volumes of gas were venting at the seabed at this time.

An important feature of a model that appeals to a remote, fluid-driven trigger for the North Sea intrusions (Fig. 12) is that the style of deepwater deposition during the latest Paleocene-early Eocene is also likely to have favored sand remobilization. At the end of the Paleocene and into the Eocene the large submarine fan complexes that had dominated the Paleocene (e.g., Andrew and Forties) gave way to a much muddier deepwater environment with only isolated sporadic sands making their way outboard of the shelf to deeper waters (Liu Xijin and Galloway, 1997), resulting in isolated, linear, gully-type or shoe-string sand bodies being deposited (e.g.,Timbrell 1993). Narrow, elongate, channel or gully-filled sands (i.e. non-leveed channel systems), and isolated sand-rich mounds (e.g.,'ponded' sand bodies) encased in claystones are those that are most susceptible to remobilization, because the lower permeabilities of the encasing mudstones provides local seals. Additionally, as indicated in Figure 12, sand bodies located above main basin forming faults, which periodically appear to have acted as vertical fluid escape pathways, were especially susceptible to remobilization. Tertiary sand bodies above leaking Cretaceous or Jurassic reservoirs would also have been susceptible to fluid induced remobilization.

\section{Conclusions}

1. Sand remobilization is widespread in deep-water sandstone reservoirs in the late Paleocene-early Eocene of the North Sea. The intervals most susceptible to remobilization comprise depositionally restricted deepwater sandstone bodies, such as narrow channels and localized fan lobes (e.g., in terminal locations), which accumulated in mud-dominated basinal settings. The latter includes both mud-rich fans and the terminal ends of sandier fan systems.

2. Remobilization results in a range of sand body geometries that are generally more complex and distinctly different from those predicted by traditional depositional models of deep-water clastic systems. The types of remobilization-related structures seen in the Paleogene of the North Sea include dike-sill complexes (e.g., Gryphon Field sands), "wings" that project outwards from the sides of sand bodies (e.g., Alba Field), sand mounds (e.g., Balder field), pockmark fills (e.g., UKCS Quadrant 15) and cone-shaped intrusions (e.g., UKCS Quadrants 16 and 21).

3. Small-scale clastic intrusions on a cm-m scale can be triggered by earthquake-induced liquefaction and localized loading of an overpressured depositional body by various autocyclic processes (e.g., mass move- 
ment, slumping, storm waves, channel avulsion, etc.). However, larger-scale $(100 \mathrm{~s} \mathrm{~m}$ to $\mathrm{km}$ ) intrusions require either high differential stresses associated with tectonic processes (e.g., as might occur in fold and thrust belts, accretionary prisms and strike-slip settings) or the sudden influx of fluid from deeper within the basin to fluidize and remobilize sand.

4. For the late Paleocene - early Eocene remobilized sandstones of the North Sea, there appear to be three critical factors: (i) a mud-dominated depositional setting containing rapidly deposited, laterally disconnected (or only poorly connected), massive and unconsolidated sands with high reservoir quality (Darcy-range permeabilities), (ii) an immediately underlying Mesozoic rift basin with an active petroleum system (i.e. containing high-quality source rocks, which reached peak maturity at or around the same time as the Paleogene deepwater sandstones were being deposited - e.g., Johnson and Fisher, 1998, Cornford, 1998), and (iii) location above Mesozoic faults enabling the upward migration of hydrocarbon fluids.

5. Remobilized and injected sands may provide additional future prospectivity in deepwater settings, both in the North Sea and in other basins globally. Injection can enhance connectivity of otherwise apparently isolated reservoir bodies. However the complex geome- tries of remobilized sands results in additional exploration and production uncertainty, compared to those deepwater sandstones influenced solely by depositional processes.

\section{Acknowledgments}

The original sponsors of this work were Fina Exploration UK Ltd, and we thank Joe Staffurth, Rod Laver and Mick Cope for help at various times throughout the project. Kerr McGee and Exxon Mobil, especially K. Purvis and M. Peacock, are thanked for facilitating Lee's access to core. D. Cole generously allowed us access to a manuscript in press. Thanks also to D. Bergslien, J. Cosgrove, D. Mohrig, P. Eichhubl, D. Pollard, P. Ware and J. Wilkinson, for fruitful discussion during the course of this work. We are grateful to P. Weimer for encouraging us to write this paper and allowing a late submission, and to the reviewers, A. H. Bouma, D. Nummendal and B. Weimer for constructive comments. L. Lonergan acknowledges funding from the Royal Society and hospitality from the Geomechanics group in Stanford during the writing of the manuscript. N. Lee was funded by NERC PhD research studentship GT0497ES72 and R.J.H. Jolly by a NERC ROPA postdoctoral grant.

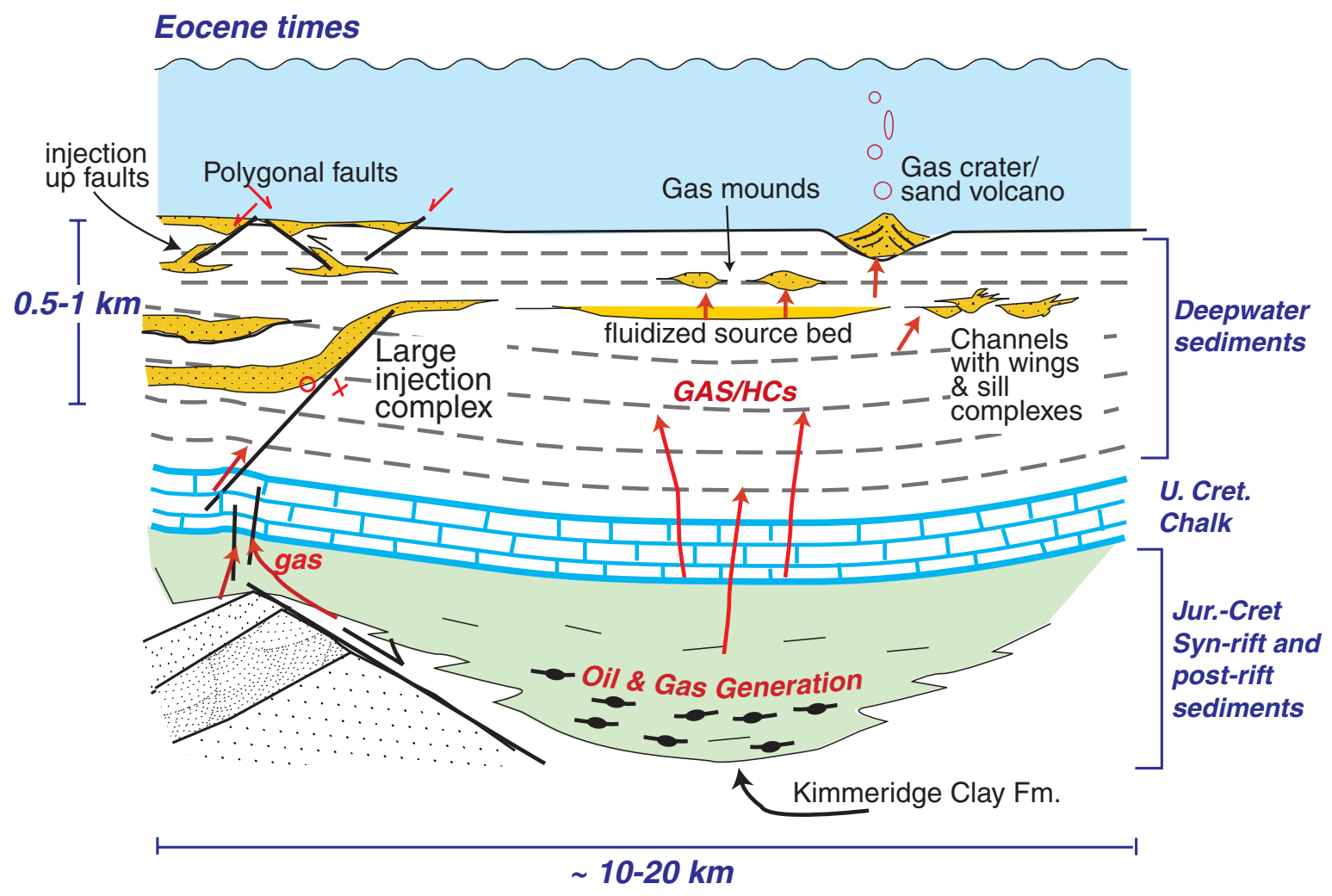

Figure 12. Summary diagram illustrating the variety of clastic intrusion and remobilization styles in the North Sea basin in the Eocene. 


\section{References}

Alexander, R.W.S., K. Schofield, and M. C. Williams, 1993, Understanding the Eocene reservoirs of the Forth Field, UKCS Block 9/23b, in: A.M. Spencer, ed., Generation, accumulation and production of Europe's hydrocarbons III: Special Publication European Association of Petroleum Geoscientists, p. 3-15.

Allen, J.R., 1985, Principles of physical sedimentology: London, George, Allen and Unwin, $272 \mathrm{p}$.

Ambraseys, N.N., 1988, Engineering seismology: Earthquake Engineering and Structural Dynamics, v.17, p.1-105.

Archer, J.B., 1984, Clastic intrusions in deep-sea fan deposits of the Rosroe formation, Lower Ordovician, Western Ireland: Journal of Sedimentary Petrology, v.54, p.1197-1205.

Baer, G., M. Beyth, and Z. Reches, 1994, Dikes emplaced into fractured basement, Timna Igneous Complex, Israel: Journal of Geophysical Research, v. 99, p.24039-24051.

Brooke, C.M., T.J. Trimble, and T. A. Mackay, 1995, Mounded shallow gas sands from the Quaternary of the North Sea: analogues for the formation of sand mounds in deep water Tertiary sediments?, in A.J. Hartley and D.J. Prosser, eds., Characterisation of deep marine clastic systems: Geological Society London Special Publication 94, p. 95-101.

Cartwright, J.A., and L. Lonergan, 1996, Volumetric contraction during the compaction of mudrocks: a mechanism for the development of regional-scale polygonal fault systems: Basin Research, v. 8, p. 183-193.

Cole, D., 1998, Large crater-like structures in the Paleogene sediments of Block 15/18, Outer Moray Firth, U.K. North Sea: unpublished M.Sc. thesis, London, Imperial College, University of London, UK, 43p.

Cole, D., S. Stewart, and J.A. Cartwight, 2000, Giant irregular pockmark craters in the Palaeogene of the Outer Moray Firth Basin, UK North Sea: Marine and Petroleum Geology, v. 17, p.563-577.

Cornfield, C. 1998, Source rocks and hydrocarbons of the North Sea, in: K.W. Glennie, ed., Petroleum geology of the North Sea : basic concepts and recent advances, $4^{\text {th }}$ edition: Oxford, UK, Blackwell Science, p.376-462.

Cosgrove, J.W., 1995, The expression of hydraulic fracturing in rocks and sediments, in: M.S. Ameen, ed., Fractography: fracture topography as a tool in fracture mechanics and stress analysis: Geological Society of London Special Publication, 92, p.187-196.

Delaney, P.T., D.D. Pollard, J.I. Ziony, and E.H. McKie, 1986, Field relations between dikes and joints: Emplacement processes and paleostress analysis: Journal of Geophysical Research, v.91, p.4920-4938.

Dewhurst, D.N., J.A. Cartwright, and L. Lonergan, 1999, The development of polygonal fault systems by syneresis of colloidal sediments: Marine and Petroleum Geology, v. 16, p. 793-810

Dixon, R.J., K. Schofield, R. Anderton, A.D. Reynolds, R.W.S. Alexander, M.C. Williams, and K.G. Davies, 1995, Sandstone diapirism and clastic intrusion in the Tertiary Submarine fans of the Bruce-Beryl Embayment, Quadrant 9, UKCS, in: A.J. Hartley, and D.J. Prosser, eds, Characteriza- tion of Deep Marine Clastic Systems: Geological Society of London Special Publication, 94, p.77-94.

Fuller, M. L., 1912, The New Madrid Earthquake: U. S. Geological Survey Bulletin, no. 494, 119p.

Hanslien, S., 1987, Balder, in: A.M. Spencer, et al., eds., Geology of the Norwegian Oil and Gas Fields: Graham and Trotman, London, p. 193-201.

Hiscott, R.N., 1979, Clastic sills and dykes associated with deepwater sandstones, Tourelle formation, Ordovician Quebec: Journal of Sedimentary Petrology, v.49, p.1-10.

Hovland, M, and A.G. Judd, 1988, Seabed pockmarks and seepages, Graham and Trotman, London, 293p.

Jenkins, O.P., 1930., Sandstone dikes as conduits for oil migration through shales: AAPG Bulletin, v. 14, p.411-421.

Jenssen, A.I., D. Bergslien, M. Rye-Larsen, and R.M. Lindholm, 1993, Origin of complex mound geometry of Paleocene submarine-fan reservoirs, Balder Field, Norway, in: J.R. Parker, ed., Petroleum geology of Northwest Europe: Proceedings of the 4th conference: Geological Society of London, p. 123133.

Johnson, H.D. and M.J. Fisher, 1998, Geological controls of North Sea hydrocarbon plays, in: K.W. Glennie, ed., Petroleum Geology of the North Sea: basic concepts and recent advances Blackwell Scientific Publications, p. 463-547.

Jolly, R. J. H, and L. Lonergan, (in review) Mechanisms of clastic dike and sill intrusion, Geological Society of America Bulletin.

Jolly, R.J.H., and D.J. Sanderson, 1995, Variation in form and distribution of the dykes of the Mull Swarm, Scotland: Journal of Structural Geology, v. 17, p.1543-1557.

Lawrence, D. A., B. Sancar, and S. Molyneux, 1999, Large-scale clastic intrusion in the Tertiary of Block 29/4, Norwegian North Sea: Origin, Timing and implications for reservoir continuity. Abstract, AAPG Bulletin, v.83, pp. 1324.

Liu, Xijin and W.E. Galloway, 1997, Quantitative determination of Tertiary sediment supply to the North Sea Basin: AAPG Bulletin v.81, p. 1482-1509.

Lonergan, L., and J.A. Cartwright, 1999, Polygonal faults and their influence on deep water sandstone reservoir geometries, Alba Field, UK Central North Sea: AAPG Bulletin, v.83, p.410-432.

Lonergan, L., J. Cartwright, R. Laver, and J. Staffurth, 1998, Polygonal faulting in the Tertiary of the Central North SeaImplications for reservoir geology, in: M.P. Coward, T. S. Daltaban, and H. Johnson, eds., Structural geology in reservoir characterization: Geological Society of London Special Publication, 127, p.191-207.

Lorenz, J.C., L.W. Teufel, and N.R. Warpinski, 1991, Regional fractures 1: a mechanism for the formation of regional fractures at depth in flat-lying reservoirs, AAPG Bulletin, v.75, p.1714-1737.

Lowe, D.R., 1975, Water escape in coarse-grained sediments, Sedimentology, v.22, p.157-204.

Lowe, D.R., 1976, Subaqueous liquified and fluidized sediment flows and their deposits, Sedimentology, v.23, p.285-308. 
Remoblization and Injection in Deepwater Depositional Systems: Implications for Reservoir Architecture and Prediction

Lowe, D.R., 1982, Sediment gravity flows: II. Depositional models with special reference to the deposits of high-density turbidity currents. Journal of Sedimentary Petrology, v.52, p. 279-297.

MacLeod, M.K., R.A. Hanson, C.R. Bell and S. McHugo, 1999. The Alba Field ocean bottom cable seismic survey: Impact on development, The Leading Edge, v.18, p.1306-1312.

Martel, A.T., and M.R. Gibling, 1993, Clastic dykes of the Devono-Carboniferous Horton Bluff Formation, Nova Scotia; storm-related structures in shallow lakes: Sedimentary Geology, v.87, p.103-119.

McGuire, D. J., 1988. Stratigraphy, depositional history and hydrocarbon source rock potential of the Upper CretaceousLower Tertiary Moreno Formation, Central San Joaquin Basin, California: Unpublished PhD thesis, Stanford University, USA, 309p.

Newton, S.K., and K.P. Flanagan, 1993, The Alba field: Evolution and depositional model, in: Parker, J.R. ed., Petroleum geology of Northwest Europe: Proceedings of the 4th conference: Geological Society of London, p. 123-133.

Newman, M. St. J., M.L. Reeder, A.H.W. Woodruff, and I.R. Hatton, 1993, The geology of the Gryphon oil field, in: J .R. Parker, ed., Petroleum geology of Northwest Europe: Proceedings of the 4th Conference: Geological Society London, p. 123-133.

Newton, S.K., and K.P. Flanagan, 1993, The Alba field: Evolution and depositional model, in: Parker, J.R. ed., Petroleum geology of Northwest Europe: Proceedings of the 4th conference: Geological Society of London, p. 123-133.

Nichols, R.J., 1995, The liquification and remobilization of sandy sediments, in: A.J. Hartley, and D.J. Prosser, eds, Characterisation of deep marine clastic systems: Geological Society of London Special Publication, 94, p. 63-76.

Obermeier, S.F., 1989, The New Madrid earthquakes: an engineering-geologic interpretation of relict liquefaction features: U. S. Geological Survey Professional Paper No. 1336-B, $114 \mathrm{p}$.

Obermeier, S.F., 1996, Use of liquefacton induced features for paleoseismic analysis: Engineering Geology, v.44, p.1-76

Price, N.J., and J.W. Cosgrove, 1990, Analysis of geological structures: Cambridge, UK, Cambridge University Press, $502 \mathrm{p}$.

Pickering, K.T., J.D. Clarke, R.D.A. Smith, R.N. Hiscott, F. Ricci Lucchi, and N.H. Kenyon 1995, Architectural element analysis of turbidite systems and selected topical problems for sand-prone deep-water systems, in: K.T. Pickering, R.N. Hiscott, N.H. Kenyon, F. Ricci Lucchi and R.D.A. Smith, eds.
Atlas of deep water environments: London, Chapman and Hall, p. 1-10.

Reading, H.G. and M. Richards, 1994, Turbidite systems in deepwater basin margins classified by grain size and feeder system: AAPG Bulletin, v. 78, p.792-822.

Rye-Larsen, M. 1994, The Balder Field: Refined reservoir interpretation with the aid of high resolution seismic data and seismic attribute mapping, in: J.O. Aasen, E. Berg, A.T. Buller, O. Hjelmeland, R.M. Holt, J. Kleppe and O. Torsaeter, eds., North Sea Oil and Gas Reservoirs III: Kluwer, p.115-124.

Sarg, J.F. and L.J. Skjold, 1982, Stratigraphic traps in Palaeocene sands in the Balder area, North Sea, in: M.T. Halbouty, ed., The deliberate search for the subtle trap, AAPG Memoir, 32, 197-206.

Scott, K.M., 1966, Sedimentology and dispersal pattern of a Cretaceous flysch sequence, Patagonian Andes, Southern Chile: AAPG Bulletin, v.50, p. 72-107.

Shanmugam. G., 2000, 50 years of the turbidite paradigm (1950s-1990s): deep-water processes and facies models-a critical perspective: Marine and Petroleum Geology, v. 17, p.285-342.

Shanmugam, G., R.B. Bloch, S.M. Mitchell, G.W.J. Beamish, R.J. Hodgkinson, J.E. Damuth, T. Straume, S.E. Syvertsen, and K. E. Shields, 1995, Basin-floor fans in the North Sea: Sequence stratigraphic models vs. sedimentary facies: AAPG Bulletin v. 79, p. 477-512.

Smyers, N.B., and G.L. Peterson, 1971, Sandstone dikes and sills in the Moreno Shale, Panoche Hills, California: Geological Society of America Bulletin, v.82, p.3201-3208.

Thompson, B.J., R.E. Garrison, and C.J. Moore, 1999, A late Cenozoic sandstone intrusion west of Santa Cruz, California: Fluidized flow of water and hydrocarbon-saturated sediments, in: R.E. Garrison, I.W. Aiello, and J.C. Moore, eds, Late Cenozoic fluid seeps and tectonics along the San Gregorio fault zone in the Monterey Bay region, California, AAPG Pacific Section, Volume and Guide book, GB-76, p.53-74.

Timbrell, G. 1993, Sandstone architecture of the Balder Formation depositional system, UK Quadrant 9 and adjacent areas, in: J.R. Parker, ed., Petroleum Geology of Northwest Europe: Proceedings of the 4th Conference: Geological Society London, p. 107-121.

Truswell, J.F., 1972, Sandstone sheets and related intrusions from Coffee bay, South Africa: Journal of Sedimentary Petrology, v.42, p.578-583.

Winslow, M.A., 1983, Clastic dike swarm and the structural evolution of the foreland and thrust belt of the Southern Andes: Geological Society of America Bulletin, v.94, p.1073-1080. 